\title{
Lumen
}

Selected Proceedings from the Canadian Society for Eighteenth-Century Studies

\section{Hercule triomphant, ou Le Despotisme terrassé (1794). A Mythological - Allegorical - Revolutionary Spectacle for the Commune of Versailles}

\section{Jack Eby}

Volume 22, 2003

URI : https://id.erudit.org/iderudit/1012258ar

DOI : https://doi.org/10.7202/1012258ar

Aller au sommaire du numéro

Éditeur(s)

Canadian Society for Eighteenth-Century Studies / Société canadienne d'étude du dix-huitième siècle

ISSN

1209-3696 (imprimé)

1927-8284 (numérique)

Découvrir la revue

Citer cet article

Eby, J. (2003). Hercule triomphant, ou Le Despotisme terrassé (1794). A Mythological - Allegorical - Revolutionary Spectacle for the Commune of Versailles. Lumen, 22, 47-66. https://doi.org/10.7202/1012258ar

Copyright (c) Canadian Society for Eighteenth-Century Studies / Sociéte canadienne d'étude du dix-huitième siècle, 2003
Ce document est protégé par la loi sur le droit d'auteur. L'utilisation des services d'Érudit (y compris la reproduction) est assujettie à sa politique d'utilisation que vous pouvez consulter en ligne.

https://apropos.erudit.org/fr/usagers/politique-dutilisation/ 


\section{Hercule triomphant, ou Le Despotisme terrassé (1794). A Mythological - Allegorical - Revolutionary Spectacle for the Commune of Versailles}

The great outdoor festivals of revolutionary France had been successful both in terms of the political education and the mobilization of the general public, but outside Paris they were loosely organized and often somewhat chaotic in nature. ${ }^{1}$ This situation changed in the first half of 1794, a period when the events of the revolution reached a fever pitch. Under Maximilien Robespierre, who had emerged from recent violent purges as the leader of the revolutionary government, the notion of public spectacle as a function of state had become a key element of policy. In May of that year he announced a law imposing universal, centrallyplanned holidays for four major celebrations: July 14 (anniversary of the taking of the Bastille); August 10 (overthrow of the monarchy); January 21 ('just punishment' of the King); and May 31 ('unity', actually the fall of the Girondins). At the same time, as part of his overall social strategy, he also presented regulations for new weekly celebrations (i.e., 10-day week), the fêtes décadaires, and introduced his new Festival of the Supreme Being, whose name was to be invoked at the opening of every ceremony from then on. This event, which would prove to be Robespierre's swansong, was held in Paris on June 8 and throughout the country at various dates in early June of 1794 .

Among those holding a festival for the Supreme Being was the Commune of Versailles, which had recently approached the idea of such festivals with great enthusiasm. They had at their disposal both a revo-

1 The best study on the subject is Mona Ozouf, Festival and the French Revolution, trans. Alan Sheridan (Cambridge, MA: Harvard University Press, 1988). Originally published as La Fête révolutionnaire, 1789-1799 (Paris, Éditions Gallimard, 1976). 
lutionary poet of some distinction in Félix Nogaret (1740-1831), and an able composer in François Giroust (1737-1799), formerly Surintendant de musique and Chapel Master of Louis XVI. It was an odd couple: Nogaret was colourful, fearless, self-aggrandizing, and something of a political loose cannon; Giroust had been the perfect church and court musician. Between them they had turned the former royal city into one of the leading centres of revolutionary entertainment outside the capital. The period of their greatest activity coincides almost precisely with the rise to power of the revolutionary government of the National Convention, late in 1793, up to the unravelling of their radical agenda under the Thermidor government that replaced them, towards the end of $1794 .^{2}$

The key figure was Nogaret. He was born in Versailles into a family of courtiers, ${ }^{3}$ and like Giroust was fully acquainted with the continuous spectacle that defined life at Versailles. He had been librarian to the Comtesse d'Artois, a comfortable sinecure that enabled him to pursue his literary ambitions. ${ }^{4}$ The only clue to his later political leanings was his active membership in the Masonic order, and his support for a charitable home in Versailles for the aged, blind, and pregnant, and for widows with large families. He was joined by Giroust in his Masonic and benevolent projects; their partnership predates the revolution by several years.

As a revolutionary, he had good political credentials. He was one of the founding members of the Amis de la Constitution, the local branch of the Jacobins, in $1790 .{ }^{5}$ He was selected as a member of the new regional government in Versailles, and later was elected to the city council. $\mathrm{He}$ also seems to have had good connections in Paris. He wrote reams of revolutionary prose, poetry, speeches, songs, and ceremonies, and regularly sent works off to the National Convention in Paris, sometimes haranguing them to pay more attention to his genius. His submissions were routinely approved and published. His writing never got him into

2 The total number of collaborations between November 1793 and January 1795 is 28 , including both songs and larger concert works.

3 His grandfather was chef $d u$ gobelet for Louis XIV, and his father held the same position for Louis XV. See Paul Fromageot, 'Félix Nogaret', in Revue de l'histoire de Versailles 6, no. 1 (1904): 2 . This article, in two successive issues of the Revue, is the only biography of Nogaret, and the best source of information on his life.

4 Fromageot, 'Félix Nogaret,' 6.

5 See Versailles, Archives municipales, $\mathrm{I}^{2}$ 1217, re Société des amis de la Constitution. A list of members in 1791 indicates he had belonged since August 1790. 
trouble, and indeed he managed to have good relations with every regime in France, during his long life, until the restoration in 1815.

He certainly supported Robespierre's views on the importance of revolutionary festivals, and for the fête of the Supreme Being supplied an ambitious and flowery cantata, which Giroust put to music. ${ }^{6}$ Only part of it was played - they later apologized that the resources of Versailles were insufficient to do justice to the entire piece. ${ }^{7}$ As for July 14, it was not yet the national day of France, and generated limited interest in Versailles.

Of greater importance both symbolically and historically was August 10 , anniversary of the date in 1792 when the monarchy had been toppled. The festival of 1794, and the events surrounding it, constituted the most ambitious, expensive and intriguing event of the entire revolutionary period in Versailles. The Conseil Général started thinking about it as early as July 5, inviting 'les artistes' to contribute their talents to the fête. ${ }^{8}$ We hear nothing more until July 22, when they again considered how to celebrate 'l'occasion de la journée du 10 Août, de la prise de la Bastille, et des avantages que nos troupes ont remportés sur les Ennemis dans les plaines du Fleurus.' Three days later, on July 25, they sent a letter to Nogaret asking for a poem to celebrate the occasion and, on the same day, sent another to Giroust telling him to write the music for the poem and arrange for any musicians that might be needed to come out from Paris. ${ }^{9}$ They apparently did not want a repeat of the Supreme Being ceremony, where the forces in Versailles were insufficient.

Meanwhile, back in Paris, the following few days saw unfolding political events reach crisis proportions. Subsequent to his threats of

6 This is the Cantate à l'Éternel, whose libretto was published by Nogaret (Versailles, l'Imprimerie de Cosson, L'an second [1794]). See Paris, Bibliothèque nationale, Ye 28585 or Versailles, Bibliothèque municipale, Pièces sur Versailles, Carton X, No.1. The music has been lost.

7 See François Giroust, 'Notte des Ouvrages Composés par le Cn Giroust,' Manuscrits F 406, Bibliothèque municipale, Versailles. 'Il est mis en musique en totalité, mais il n'a pu être exécuté à Versailles que par extrait. Paris seul fournirait les moyens nécessaires à son exécution.'

8 Versailles, Archives municipales, Registre des assemblées du Conseil général de la commune de Versailles, Vol. 6, p. 4, for 17 Messidor (July 5). (Hereafter cited as Registre).

9 Extract from Registre, Vol. 6, found in Versailles, Archives municipales 2190, p. 50, for 4 Thermidor (July 22), and p. 51, for 7 Thermidor (July 25). Giroust could hardly have done anything before getting the completed (and approved) text; this ignorance of the artistic process was all too typical of his civic employers. 
even more purges, Robespierre was overthrown on July 27, and was executed the following day. The country was thrown again into a state of upheaval. Events were followed breathlessly in Versailles. Who was in charge? What were their views? Of more immediate concern, what to do with the fête of August 10, now less than two weeks away?

On August 6, the council had Nogaret's poem in hand. Had it been tailored to suit the context of recent events? Quite possibly it was. The council now described the festival as a celebration 'des Victoires de la République et de la chute du Despotisme, ${ }^{10}$ a term that allowed for various readings, especially since in the minutes of this very meeting, immediately after a breathless description of the events surrounding the fall of Robespierre, comes the following quotation: 'la defaite des tirans sera l'objet de nos Chants au Temple de l'Éternel. ${ }^{11}$ From that same meeting of the 6th we find also a note to the director of the National Theatre asking for some actors, a notice to musicians to get in touch with Giroust, an order that a programme with Nogaret's text be printed, and (wisely) a decision to postpone celebrations for a week, until 17 August.

With the luxury now of a week and a half to prepare, all went off well on the 17th. The highlight of the various ceremonies was the new work by Nogaret and Giroust, titled Hercule triomphant, ou Le Despotisme terrassé. ${ }^{12}$ The site for this show was the natural amphitheatre at the end of the Eau des Suisses, a small lake to the south of the château, where an enormous stage (soixante pieds ${ }^{13}$ ) had been erected. The main work was to be preceded by a new song entitled Tyrtée aux plaines de Fleurus, ${ }^{14}$ which dealt with recent victories of the Republic (see Appendix 1). The Battle of Fleurus had taken place on June 26, near the city of Charleroi,

10 Ibid., p. 51v, for 19 Thermidor (August 6). The minutes give the complete libretto.

11 In the Registre, Vol. 6, p. 78, for the same date.

12 Hercule triomphant, ou Le Despotisme terrassé, poème lyrique composé par Félix Nogaret, d'après l'invitation du comité d'instruction publique de la Commune de Versailles ... (Versailles, De l'imprimerie de Cosson, dated le 30 Thermidor, An II [August 17, 1794]). See Paris, Bibliothèque nationale, Ye 28591. The publication included extensive notes as well as the complete text for Tyrtée aux Plaines de Fleurus and the first verse of the Les Déserteurs.

13 This useful information comes from a later publication of revolutionary texts by Nogaret, his L'Ame de Timoléon, ou principes républicains, philosophiques et moraux (Paris, Chez Delaplace, An VI [1797-98]), p. 134.

14 Tyrtée aux Plaines de Fleurus (Paris, Chez Frere, No. 226 [1794]). See Paris, Bibliothèque nationale, $\mathrm{Vm} 716880$. The transcription is by the author, and all the original spellings have been kept. 
in what is now southern Belgium. The French defeated the Austrian army in one of their first great victories over the coalition of forces ranged against them. Nogaret penned an appropriate song, which was already approved by the National Convention before it appeared on this occasion. ${ }^{15}$ Giroust wrote the tune (a fine march); it is one of the few fragments of music to survive from the ceremony.

As for the main feature, Hercule triomphant was a semi-dramatic oratorio (on his title page Nogaret calls it a 'Poème mis en action') with elaborate staging and costumes, and mimed action, accompanied by recitatives, choruses, and descriptive orchestral music. Nogaret confesses that he had based this work on a poem on which he had already been working, in which the trials of Hercules are compared allegorically with those of the French people. Since he had been given very short notice, this is hardly surprising, and it would go far to explain the hybrid character of the text. It does not seem that any more of this proposed poem was ever actually written than what appears in this piece, ${ }^{16}$ and the mythological backdrop of the opening pantomime will give way to quite a different theatrical premise as the work unfolds. (The full libretto is given in Appendix 2.) The evolving imagery is almost as confusing as the politics of the moment. Where does it all come from, and what is its purpose?

The most obvious point is that the work is based mostly on classical antiquity. This is entirely typical of the imagery of many revolutionary festivals. Mona Ozouf calls it the 'obsessive yet mysterious recourse to antiquity. ${ }^{17}$ Why Ancient Greece and Rome should have dominated creative minds in revolutionary times has been much discussed. Every school boy in France (as well as the rest of Europe) studied the ancient world. For an eighteenth-century thinker it was the natural point of reference, both intellectually and artistically. This was true long before 1789 , but there were compelling new reasons to turn to the classics in revolutionary France. On a political level, antiquity offered examples of successful republics - Athens, Sparta, Rome - as well as a variety of republican heroes and models. Busts of Brutus, for example, would join

15 Hercule triomphant, note to title page.

16 Nogaret published a brief prose summary of his plan as Parallèle de l'Hercule français avec l'Hercule des Grecs (Paris, Linant, An III [1794-95]). See Paris, Bibliothèque nationale, $\mathrm{Lb}^{41} 1333$.

17 Ozouf, 271. 
those of Voltaire and Rousseau, and of various early martyrs to the revolutionary cause, as objects of veneration. ${ }^{18}$

Furthermore, the recent and fierce campaign of de-Christianization had seen all the churches closed and turned into Temples of Reason in December of 1793. In the absence of Christianity, and of its ceremonies and symbols, the government was looking for something to address the spiritual needs of its citizens. Antiquity offered several useful features. It predated Christianity and so could be said to have a prior claim on human civilization. It could be presented as 'the Golden Age' of humanity and came complete with philosophy, reason, moral codes, and social models, which could be deployed selectively. And it spoke a language that everyone read in school, saw in the theatre or in the opera house, or viewed in paintings or in the architecture around them. Nogaret was a classical scholar. ${ }^{19}$ Versailles city officials deferred to him just as in Paris they deferred to David, who organized the festivals there.

So, who is the Tyrtee of the revolutionary song? He was a philosopher and poet from ancient Sparta, who lived at about $650 \mathrm{BC}$. He is described in Plutarch, everyone's favourite source at this time, ${ }^{20}$ as 'a man who is good for whetting the spirits of the young.' Among his surviving poems is one urging the youth of Sparta on to battle:

in your left hand brandish your shield

fiercely shake your spear

without fear for your lives:

that is not the tradition of Sparta. ${ }^{21}$

This was an excellent model for the young French soldiers at Fleurus and a poetic inspiration for Nogaret's own bellicose verses.

As for the story of the 12 labours of Hercules, it is one of the bestknown in Greek mythology, but why would Nogaret go here for his

18 Brutus was honoured in Versailles as a martyr on January 19 and January 291794. See Registre, Vol. 4, p. 231 for 21 Nivôse (January 19), and p. 257 for 10 Pluviôse (January 29).

19 In 1829 , at the age of 89 he saw, and was scandalized by, Hugo's Hernani. He published a scathing review, in the title of which he refers to himself as '[un] vieux classique Aristénète'. See Fromageot, 150.

20 Ozouf, 273. ' ... it was through him alone that the men of the Revolution knew Greek antiquity'.

21 Quoted in the website Noctes Gallicanae:

$<$ http://noctes-gallicanae.org/Lyriques\%20grecs/tyrtee.htm>. 
source? Classical mythology is much less present in the symbols of the French revolution than is historical antiquity, and with the Chateau de Versailles across the lake filled floor-to-ceiling with mythological images, was there not a particular danger of confusion $?^{22}$ And what about Reason, or the Supreme Being? The short answer is that Nogaret used Hercules here because he was already writing a poem on the subject. We might then ask, why write a poem with this theme? A useful aspect of myth is that it was easily employed as allegory. In his proposed poem, Nogaret was trying to wrest the great mythological hero away from his royalist connections, and thereby bend the power of Greek myth to the service of French citizens. It is quite a leap from the prodigious tasks of Hercules to the political travails of revolutionary France, but allegory can be wonderfully vague when it has to be. August of 1794 was a good time to be vague.

An excellent example of this obfuscation is the figure of Hydra, who is the only adversary Hercules actually fights and overcomes in this reduced version of the labours. In the extensive endnotes to the published libretto, which was on sale to the public, Nogaret explains at some length what the Hydra represents. ${ }^{23}$ He gives not one, but two different explanations. The more obvious one relates to 'the Coalition', i.e. the foreign powers who were fighting to reimpose the French monarchy. There are more than the mythological seven heads to this Hydra: George III of England, Francis II of Austria, Frederick William of Prussia, William V of Holland, Victor-Amadeus III of Piedmont, Ferdinand of Naples, Charles IV of Spain, and Catherine of Russia, with Pope Pius VI thrown in for good measure. The implication is that the French have matched Hercules' triumph over the Hydra with their victory at Fleurus. Or, writes Nogaret, the seven heads represent a new set of deadly sins: royalism, federalism, atheism, fanaticism, treason, assassination, and famine. Fanaticism-treason-who are we talking about? Have the French now been equally successful against this Hydra?

But that is not all we get of allegory. We meet a whole cast of allegorical figures who not only share the stage with our mythological hero, but also eventually take over the show. The mythological Cyclops and Furies are quickly overshadowed in the struggle between DESPOTISM and LIBERTY. Hercules never encountered the latter two, nor that

22 The impressive Salon d'Hercule, for example, is the first room one visits on present-day tours of the Château.

23 Hercule triomphant, Note 4, p. 12. 
surprising child of 'the hatred of Kings': CIVISME! In passing, Nogaret tells us that Despotism was predicted by Samuel, which it was (I Samuel 8:10-18). These are strange bedfellows, Samuel and Hercules. Despotism was the usual codeword for the monarchy, but the term was ambiguous enough to embrace other 'tyrants' such as, for example, the recently-departed Robespierre. Liberty is the central image of much revolutionary iconography, although here she is not the dashing female warrior of Delacroix, but rather a pitiable victim, who is freed from her chains after Hercules defeats the Hydra. Also feminine is EQUALITY, who will take the place of the fallen Hydra, and VICTORY, who has better antique credentials than the others, and who arrives in her own chariot. None of these ladies actually says or does anything other than carry us out of the picturesque action of Greek mythology (Hercules just fades away) and into the higher realm of political and social ideals, which is Nogaret's true goal.

Into this allegorical party is now brought the ROCK OF EQUITY, representing, says Nogaret, 'la partie incorruptible du Senat français.' There are surprisingly few references to the National Convention as a 'Senate' during this period; the reference here is probably antique again. In a climax of mixed imagery the Rock is portrayed as a pyramid, which sounds masonic; is carried by 'Des Atlas', one last (if inexact) allusion to Hercules; and replaces the trophy of Despotism. Anyone who did not buy the libretto could be excused for feeling lost.

Mention of the government brings us to a more politically engaged part of the ceremony, where the crowds will be addressed directly. The first speaker will be NATURE who, we are told later only in passing, is the voice of the Great or Supreme Being ('grand-ETRE'), and who in a dramatic recitative will discourse on THE RIGHTS OF MAN. That the Supreme Being was the source of the natural rights of man was Robespierre's vision, and the concept was closely linked to his person. Subsequent to his dramatic demise, it is not surprising that the Supreme Being gets only a supporting role here. Nogaret says the voice of Nature is to be like an ORACLE, which is once more antique, although the image of a voice coming 'comme l'éclair d'un nuage' would probably have brought to mind instead an Old Testament figure - say, Moses. It is unfortunate that we do not have Giroust's music for this passage: he did write an oratorio on the Ten Commandments! $!^{24}$ 
Into this solemn scene enters the MAYOR, carrying the Rights of Man, just like Moses with the tablets of stone. We might find it odd to see a local politician, in a quasi-religious role, sharing the stage with Hercules and Nature, and yet their function is clear: to bestow authority on him, and what he represents, which is the political reality of the revolution to the citizens of Versailles. (It is not clear if Mayor Gravois himself actually appeared at this point in the production. He had been appointed Versailles' fifth mayor in six years. ${ }^{25}$ Four months, almost to the day, after this festival, he would commit suicide, and on the next day the whole council would be replaced yet again.) As the grand and logical finale to the spectacle, THE PEOPLE themselves are brought into the drama, as the mayor commands them to swear to uphold the Rights of Man. This everyone could understand, and they do. Then the singing and dancing begin.

The concluding song is another new composition, Les Déserteurs, ronde dansante. ${ }^{26}$ (See Appendix 3.) The political context of the lyrics is less precise than Tyrtée; the only name mentioned is the Duke of Brunswick, hated leader of the allied coalition, whose name pops up frequently in this repertoire. Nogaret's verse is a curious cross of bucolic and virulent, although Giroust's charmingly innocent melody largely subverts the political element. The refrain is another example of Nogaret's finelytuned ambiguity:

Nous venons rire et boire,

Chanter, danser avec les bons enfans,

Et faire sauter les tyrans,

Pour couronner l'histoire.

Along with the municipal council, the average citizens of Versailles no doubt welcomed the recent fall of 'les tyrans', and probably felt they had some reason to sing and dance.

25 Thierry de Ville-d'Avray, who was officially named mayor only in May, 1789, 'retired' in August of that year. He was succeeded by Jean-François Coste in February, 1790; Hyacinthe Richaud in November 1791; Jean-Jacques Huvé, in the middle of 1793; and Pierre-Charles Gravois, who was appointed in September 1793 after the recently arrived local representatives of the National Convention, Delacroix and Musset, dismissed the previous council.

26 Les Déserteurs, ronde dansante (Paris, Chez Frere, No. 149 [1794]). See Paris, Bibliothèque nationale, $\mathrm{Vm} 7$ 16866-67. Transcription by the author. 
What would the contemporary audience, however, make of this whole show? Remember that the action was presented as a pantomime, accompanied by music. They must have been mystified much of the time, unless the local Comité d'instruction took Nogaret's advice and explained everything to the crowd beforehand, or unless they all had bought the libretto (three thousand copies were printed ${ }^{27}$ ), and read the several pages of footnotes in fine print, which have proved very useful for this study. In those notes, Nogaret writes

Si j'ai demandé qu'on me permit de placer ici quelques notes, c'est que je n'écris pas pour les hommes instruits: c'est qu'un ouvrage est mal aujourd'hui, s'il n'est pas entendu de tout républicain; et que je ne connais pas de plus sotte vanité que celle de rester inintelligible. ${ }^{28}$

Was this intelligible to the average Versaillais? Those three thousand librettos seem to have sold pretty well since Nogaret later wrote that the citizens of Versailles did not actually have to pay for this extravagant entertainment - the single most expensive show ever put on in Versailles. ${ }^{29}$ Most of the cost was in fact covered by the sales of this pamphlet and of songs by Giroust. ${ }^{30}$

While one is obliged to admire the ambition of this endeavour, the results cannot possibly have equalled the intent. As both Nogaret and Giroust would have known, it was hard to impress citizens of the city that had defined spectacle for all Europe over many generations. One resident of Versailles, writing about it some years later, gives a jaundiced review. ${ }^{31}$ After an amusing description of the events of the pantomime,

27 Versailles, Archives municipales, I1 1041 Fêtes officielles, An II (Dépenses). Doc. E 3 includes printing bills for the year: ' 3000 exemplaires du Poême Le Despot terrasé'.

28 Hercule triomphant, Preface to Notes, p. 11.

29 Versailles, Archives municipales, I1 1041 Fêtes officielles, An II. Document E 1 lists expenses for the year (see 11 Ventôse An 3 [March 1, 1795]): 'pour la fête du 30 Thermidor de l'an 2 - 2,202/ 9 (livres)'. This was, for comparison, twice as much as was spent on the Festival for the Supreme Being in June 1794. Festivals later that fall cost 160 and 139 livres.

30 L'Ame de Timoléon, 134: '(nota bene) sans aucune importunité de la part des habitans, pour subvenir aux frais, qui furent considérables.' Document E 1 says that sale of printed material related to the festivals for the whole year totaled 2,263 livres, which means Nogaret was not exaggerating overly.

31 Souvenirs écrits sous la dictée de Madame L., Versailles, Archives départementales des Yvelines, $1 \mathrm{~F} 44$. 
she says laconically 'On chantait toujours.' What stood out in her mind? 'Il est arrivé une fois que la déesse vêtue de mousseline claire ayant eu froid ou peur excite une immense hilarité: sa robe étoit entièrement gâtée à l'endroit où elle s'était assis. Je l'ai vu.' She adds that Hercules was a local milk carrier named Nicolas. Despite the gap between the nobility of the work's conception and the reality of its performance, however, Nogaret would later write that this was 'le plus magnifique des spectacles que l'amour de la Liberté ait enfanté dans cette commune. ${ }^{32}$ Alas, except for the two songs, the music is lost and we will never know.

Although the Comite d'instruction publique in Versailles had given it its blessing, and despite its success, at least in the eyes of some, this kind of show was in a sense exactly what Robespierre had attempted to suppress. How easy it would be for political heresy to slip in or for an unauthorized subtext to be implied. As the new Thermidor government gradually repealed many of the more drastic revolutionary laws, the impetus for festivals diminished. After the ceremony for 'the just punishment of the king' in January of 1795, these events virtually cease in Versailles, not be renewed until a later government (the Second Directory), decided they were politically useful and imposed a whole new set of them in 1798. For a more jaded populace, however, none of these new festivals would generate the same degree of enthusiasm as the earlier ones. Indeed it is hard to imagine how a celebration of youth, or old age, or marriage or agriculture, could ever match either this imaginative and exotic spectacle depicting Despotism overthrown, or the real-life drama that had preceded it.

\section{JACK EBY}

Bishop's University 
58 Jack Eby

\section{Appendix 1:}

\section{Tyrtée}

\section{Tyrtée aux Plaines de Fleurus, Hymne Guerrier.}

Demandé par la CONVFNTION a Agrée par elle. Paroles de Fílix Nogaret, Musique de Giroust.
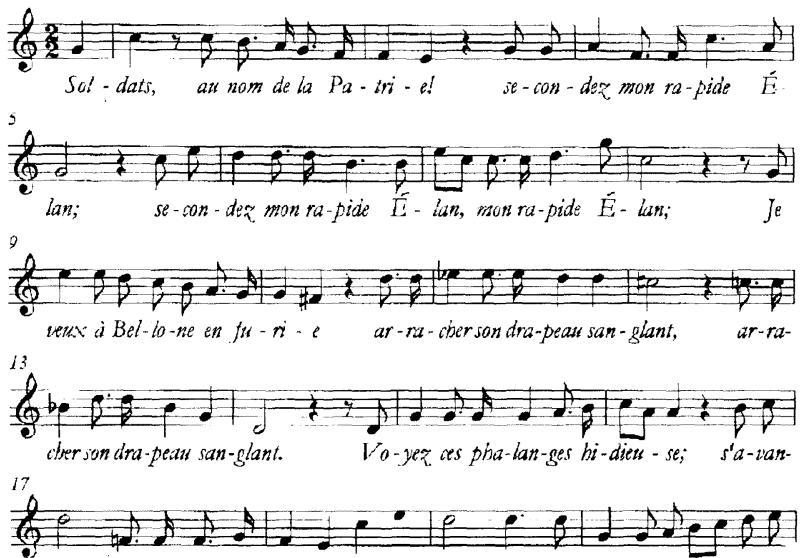

cer... bas-ie-ment beu-rew-ses de ser - vir des ty-rans! Il en faut, il en
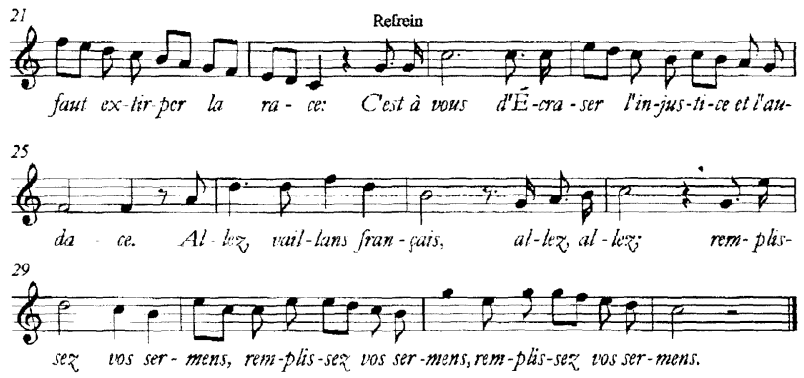

2

Paraissez brigands de la terre!

Osés combattre les Français; (bis)

Il ne faut pas un vain tonnerre

Pour mettre un terme à nos succès! ... (bis)

Nous saurons, vainqueurs de nos crises,

Attacher à vos entreprises

Les revers infamans.

Que l'effet suive la menace!

C'est à vous d'écraser Ec. 
3

Fille et compagne de Bellone

La Liberté met dans nos mains

Le fer, dont le tranchant moisonne

Les rois ennemis des humains.

Monstres couverts d'ignominie:

Ils tentent, pour la tyrannie,

Des efforts impuissans.

Remettez le Peuple à sa place:

$C^{\prime} e s t$ à vous d'écraser $\mathcal{E} c$.

4

Tombez bondissez sur l'enclume

Frappez l'acier pesans marteaux!

Que le salpêtre se rallume;

Que Vulcain prête ses fourneaux!

Il est tems que la foudre gronde

Et, sur tous les trônes du monde.

Roule en feux dévorans:

Gardez vous d'en laisser la trace;

$C^{\prime}$ est à vous d'écraser $\mathcal{E} c$.

\section{5}

C'en est fait; l'Aigle Germanique

Voit ses escadrons dispersés.

Allez, marchez dans la Belgique

Sur les cadavres entassés.

Dans leur camps portez les allarmes;

Furieux qu'ils tournent leurs armes

Contre leurs chefs palissans.

Soulevez l'Univers en masse.

$C^{\prime}$ est à vous d'écraser $\mathcal{E}$ c.

$\overline{\text { Se trouve a Versailles chez Giroust au Palais National. }}$ 


\section{Appendix 2:}

\section{Hercule triomphant, ou Le Despotisme terrassé}

\section{Félix Nogaret and François Giroust}

[Translation of the rubrics into English by the author]

In the vast locale of the eau des Suisses rises a bare rock, on which appear, in the form of a trophy, the attributes of DESPOTISM. Emblem of the Coalition, the Hydra protects it, unnoticed.

Before this rock lies LIBERTY, moaning, chained to a globe; the chains falling from her hands also surround the globe. Cyclops and Furies are busy forging more chains, at the order of Despotism.

A soloist:

Fille de Ciel! Reine de l'Univers!

Liberté! Liberté! quelles mains sacrilège

Au mépris de tes privilèges,

Ont osé charger de fers?

Tu gémis! je t'entends: Ah! c'est le DESPOTISME,

Monstre annoncé par Samuel:

La Terre en a frémi ... mais le monstre est mortel: ...

Que la haine des Rois enfante le CIVISME! ...

Peuples, frappez le criminel.

At the mention of LIBERTY, Hydra, now awakened, comes out of a darkened cave and, by a tortured route, approaches the sceptres and daggers under its protection.

The people:

Répondons à la voix divine

Qui nous invite à recouvrer nos droits:

Plus de Rois.

Répondons à la voix divine

Qui nous dit de frapper les Rois,

Et nous rend à notre origine:

Peuples, d'une commune voix

Disons, répétons: Plus de Rois.

Jurez / Jurons de recouvrer nos droits.

(Bruit de guerre.) 
HERCULES arrives in a triumphal chariot, surrounded by warriors.

The French people:

Modèle des héros! destructeur des Brigands!

Entends le cri de la vengeance:

Parais Alcide, avance:

Guide nos coups, frappe: il est tems

D'écraser les tyrans

Ligués contre la France.

Fier vengeur de l'humanité!

Descends de ton char de victoire:

Nos guerriers sont jaloux de partager ta gloire

Et ta double immortalité.

Chorus of praise:

De Castor et de Rhadamante

Digne élève! ... au mépris des fureurs de Junon,

Sa massue a frappé le monstre d'Erymante,

Le lion de Némée, Anthée et Gérion!

Sur son trône de fer il fut pâlir Pluton: ...

Tu fus rendue, Alceste, à ses mains triomphantes!

De l'hydre, affreux serpent d'un marais infecté,

Il a broyé les têtes renaissantes: ...

Il a vaincu la volupté!!!

(Reprise.)

Fier vengeur ....

HERCULES descends from his chariot, and advances, accompanied by his emulators. With his club he battles the HYDRA and overthows its attributes. (Musique analogue)

LIBERTY is set free by the warriors, who break her chains. A new trophy is elevated where the Hydra had been; this trophy offers the attributes of EQUALITY, on which young citoyennes drape garlands of flowers.

A chorus of nymphs:

Avec la Liberté, l'Égalité respire! ...

Elle offre à nos regards ces attributs sacrés,

Effroi de l'oppresseur qui contre nous conspire! 
Ovous, si longtems désirés!

Soyez les gages assurés;

Soyez le salut de l'Empire.

\section{A chorus of Warriors:}

Le despotisme est terrassé!

Chantons la gloire de nos armes:

L'Égalité l'a remplacé!

Chantons, amis, chantons la gloire de nos armes.

Qu'un cri de joie éclate et succède aux alarmes!

Chantez, Français, chantez la gloire de vos armes.

Le Colosse n'est plus; il tombe renversé:

Son trône disparait et son règne est passé.

VICTORY, to the music of a triumphal march, approaches in her chariot.

Couplets to the Goddess:

Fille du Styx et de Pallante,

Victoire! donne à tes enfants,

Donne la palme triomphante,

Due à leurs travaux éclatans,

Si tu ne suis que la vaillance,

Tu peux rester en assurance

Au milieu du peuple français;

Glorieux de la préférence,

Ils ne te quitteront jamais.

Tu connais l'ardeur qui nous guide

Et nous fait voler aux combats!

Ton char même, ton char rapide

Est dévancé par nos soldats.

Tu n'as point d'amis plus fidèles:

Je vois tes palmes immortelles

Moins nombreuses que nos succès.

$C^{\prime}$ est trop longtems porter des ailes;

Dépose-les chez les Français.

The Roc d'équité, symbol of the incorruptible party of the French Senate, appears and is brought forward by some Atlases, who substitute this pyramid for the trophy of Despotism. 


\section{NATURE (baritone)}

Peuples faites silence ... Aux accens de ma voix

Que l'Univers entier tressaille d'alégresse!

La force est du côté que parat la faiblesse: ...

Je vais vous retracer vos DROITS:

RIGHTS OF MAN. Disjointed song ('Chant décousu'), in the style of the ORACLES. The words issue from the music like lightening from a cloud.

NATURE

Au Peuple, sans partage, est la toute-puissance,

Et ce n'est qu'a ses loix

Qu'il doit l'obéissance. (Trait de symphonie)

$Q u^{\prime} u n$ fer vengeur perce le sein

De qui s'attribuerait le pouvoir souverain! (Trait de symphonie)

Ou paraitra la tyrannie,

Fais résistance à l'Oppresseur.

(Idem.)

Parle, écris à ton gré; propage ton géniel

(Idem.)

Prie et sers qui tu veux: ton juge est dans ton cœur. (Idem.)

Des secours te sont dûs, et la dette est sacrée;

Tu vivras, sans rougir, citoyen malheureux!

Tes frères préviendront tes vœux;

Ton existence est assurée.

(Idem.)

Français, livrez à l'espérance

Un cour trop long-temps abattu:

Les honneurs sont la recompense

Des talens et de la vertu.

(Idem.)

The MAYOR approaches the Rock; holding in his hands the RIGHTS OF MAN.

The MAYOR in the name of the people: 
Ô Nature! ô Raison! que l'Univers t'implore!

Tu fais d'un peuple esclave un peuple souverain ...

L'auguste Liberté, cet attribut divin

Dont l'absence nous déshonore;

La liberté, qui vient d'éclore

De toute éternité fermentait dans ton sein.

(Pause)

Ô Nature! ta voix est celle du grand-ETRE: ...

Elle appelle au bonheur l'homme régénéré.

(Pause)

Voici nos droits! ... voici ce Code reveré! ...

(Serment.)

Plutôt de le méconnaître,

Plutôt qu'on vous ravisse un dépôt si sacré,

Français ..., jurez de cesser d'être.

The PEOPLE:

Nous le jurons.

General happiness. The festival ends with La Ronde nouvelle by the same authors.

Or, écoutez gentils Français,

La Carmagnole et vos succès

Charment les cours et les oreilles:

La Liberté fait des merveilles;

Vous en voyez les bons effets ...

Nous venons rire et boire,

Chanter, danser avec les bons enfans,

Et faire sauter, sauter les tyrans

Pour couronner l'histoire, etc. etc. etc. 


\section{Appendix 3:}

\section{Les Déserteurs}

\section{Les Déserteurs, Ronde Dansante.}

Paroles de Félix Nogarct, Musique de Giroust.

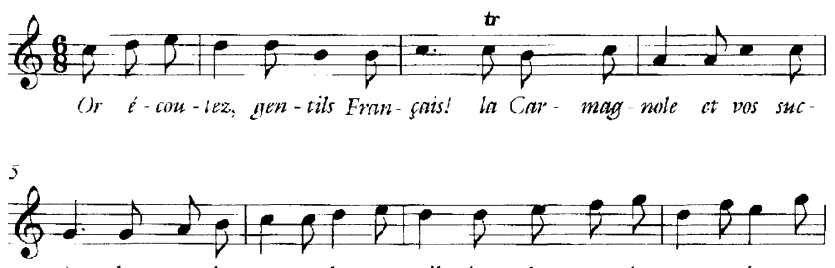

cès, char-ment les coours et les o- reil-les, char-ment les coeurs ot les o-
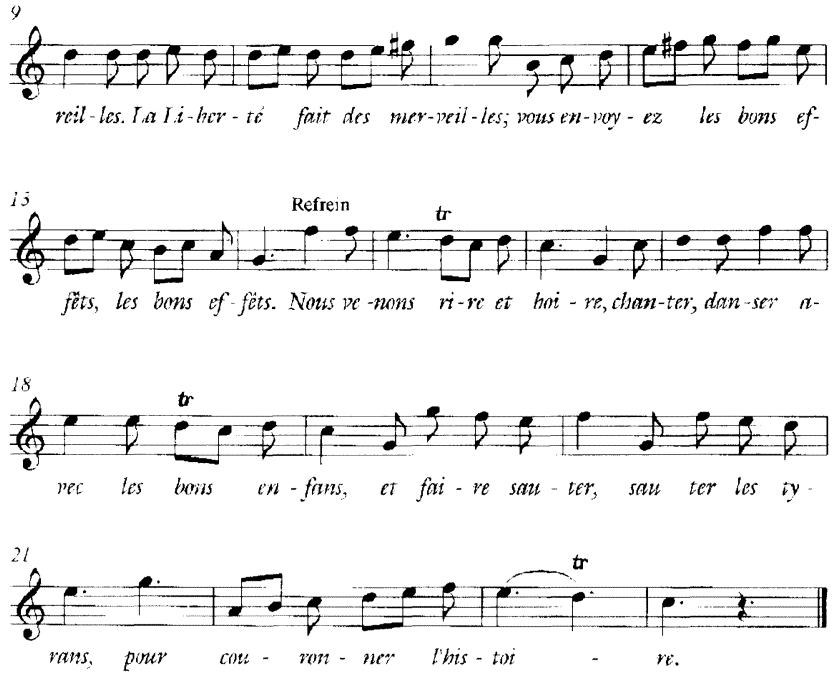

2

On vous dit un peuple de fous:

Nous voulons l'être comme vous.

Plus de maitres, plus d'esclavage.

Vive l'Oiseau sorti de cage!

Foin des Brunswik! qu'il crevent tous!

Nous venons rire, Ec. 
3

Nos Généraux, vrais capucins

Vous appellent Brûleurs de saints,

Tueurs de Rois, Gibier du Diable;

Mais le fer, qui les pique au râble,

Sert joliment vos grands désseins.

Nous venons rire, $\mathcal{E} c$.

4

Le tems est venu de songer

$Q u^{\prime}$ on est fou de s'entregorger

Pour des Caffards et des Despotes;

Que du côté des Sans-culotes,

On fait fort bien de se ranger.

Nous venons rire, Ec.

5

Amis, soyez les bien-venus!

Vous n'êtes pas des plus charnus:

Avant tout il faut vous refaire.

La bas, du plat du cimetère

Par vos chefs vous etiez battus;

Vous allez rire et boire,

Chanter, danser avec les bons enfans,

Qui feront sauter vos tyrans

Pour couronner l'histoire.

Se trouve a Versailles Chez Giroust 